\title{
Razlike v prostorskih vzorcih mestnega turizma na Dunaju in v Pragi
}

Dunaj in Praga sta pomembna srednjeevropska turistična kraja, ki ju je v letu 2011 obiskalo enako število tujih turistov. Čeprav sta mesti približno enako veliki in imata podobno kulturno turistično ponudbo, se močno razlikujeta po prostorski razporeditvi turistov in njihovi rabi prostora. Mestno središč Prage je znano po zastojih, prenapolnjenosti in enofunkcijski rabi, medtem ko središče Dunaja obišče podobno število gostov, vendar si pri tem lokalne funkcije in turizem ne nasprotujejo. Na podlagi podatkov, pridobljenih s pomočjo geografsko označenih fotografij obeh mest, ki so bile objavljene na spletnih straneh za izmenjavo fotografij, smo izdelali grafa prostorske razporeditve turističnih znamenitosti in poti. Z analizo teh primerljivih grafov smo lahko pojasnili razlike $\mathrm{v}$ turističnih sistemih obeh mest, ki so povezane predvsem z njuno morfološko zgradbo in različnimi pristopi $\mathrm{k}$ razvoju mestnega turizma v preteklem desetletju.

Ključne besede: mestni turizem, urbana morfologija, vpliv turizma, raba mestnega prostora, geografsko označevanje, Dunaj, Praga 


\section{Uvod}

Dunaj in Praga sta svetovno znana po svojih zgodovinskih mestnih predelih, arhitekturnih znamenitostih in kulturni ponudbi. Po podatkih informacijskega sistema TourMIS (2012) je bila Praga leta 2011 na seznamu najbolj obiskanih mest Evropske unije na šestem, Dunaj pa na sedmem mestu, pri čemer je Praga zabeležila večje število nočitev, Dunaj pa večje število prihodov turistov. Dunaj, Praga in Budimpešta so mesta, za katera se turisti radi odločijo, kadar za konec tedna načrtujejo obisk določenega kraja, veliko ljudi pa jih obišče kar skupaj v sklopu krožnega potovanja po Srednji Evropi (Puczkó in Rátz, 2000). Ta tri pomembna mesta nekdanje Habsburške monarhije imajo podobno turistično ponudbo, vendar pa $\mathrm{v}$ zadnjih 20 letih Budimpešta pritegne pol manj gostov kot drugi dve mesti. Na prvi pogled imata Dunaj in Praga podobno turistično dejavnost, vendar med njima obstajajo pomembne razlike v zgodovinskem razvoju, urbanističnih praksah in upravljanju turističnih destinacij. Enako število turistov prihaja v mesti z različno morfologijo in povzroča v njiju skoraj nasprotne turistične učinke na lokalni sistem.

V mestih se turisti ukvarjajo z najrazličnejšimi stvarmi: obiskujejo znamenitosti, spomenike, muzeje in kulturne prireditve, nakupujejo, obiskujejo restavracije in se družijo z drugimi ljudmi. Na svetovnem trgu mesta med seboj tekmujejo za turiste tako, da razvijajo svoje znamenitosti in okolico. V zgodovinskih turističnih mestih (Ashworth in Turnbridge, 1990), kot sta Dunaj in Praga, pa gre pri večini znamenitosti za spomenike na zgodovinskih krajih z zaščiteno morfologijo, ki jo obenem uporablja tudi lokalna skupnost s svojo infrastrukturo, podjetji in kulturnimi ustanovami. $\mathrm{V}$ prejšnjem desetletju sta ti mesti svojo turistično ponudbo obogatili z boljšimi conami za pešce v središču, razvojem kulturnih turističnih storitev, izboljšano trgovsko ponudbo ter obnovo ulic in zgodovinskih stavb. Ker pa se zdaj vse več obiskovalcev zbira na javnih, pešcem prijaznih krajih okrog glavnih znamenitosti, zmanjkuje prostora za lokalno rabo. Trgovine z živili in delavnice se spreminjajo $\mathrm{v}$ trgovine $s$ spominki, lokalne gostilne $\mathrm{v}$ drage restavracije in stanovanjski bloki v hotele, saj so te storitve zdaj donosnejše. Domačine običajno gneča v njihovih soseskah moti, zato se preselijo v predmestje ali druge mirnejše mestne predele, $\mathrm{v}$ katerih je na voljo več parkirnih mest in lokalnih storitev. Zaradi te selitve postane mestno središče območje $s$ samo eno funkcijo in začne se spreminjati v muzej oziroma zabaviščni park, pri čemer izgubi svoj urbani značaj (McNeil, 1999). Boštjan Bugarič (2006) ugotavlja, da »spreminjanje mest v turistična območja « poslabša kakovost življenja in zmanjša javno prisotnost mestnih prebivalcev. Ta proces in negativne posledice zgoščanja turistov $\mathrm{v}$ mestih so preučevali strokovnjaki, ki so analizirali njihov vpliv na odnos lokalnih prebivalcev (glej
Gilbert in Clark, 1997, in Deichmann, 2002) in obiskovalcev (glej Simpson, 1999, ter Riganti in Nijkamp, 2008).

Objavljene raziskave (glej Johnson, 1995; Cooper in Morpeth, 1998; Hoffman in Musil, 1999; Simpson, 1999; Deichmann, 2002, ter Hoffman in Musil, 2009) podpirajo našo domnevo, do katere smo prišli z analizo lokacije turistične in lokalne infrastrukture in na podlagi izkušenj na kraju samem, in sicer da obstaja v Pragi veliko več teh pojavov. V središču Prage je več turistov, kar povzroča gnečo ter skoraj popoln umik lokalnih uporabnikov in infrastrukture, medtem ko so si na Dunaju turisti prisvojili samo določena območja v mestnem središču. Pojavlja se vprašanje, zakaj se lahko pritisku podobnega števila turistov eno mesto upre, drugo pa ne.

V članku se osredotočamo na glavne razlike v rabi turističnega prostora $\mathrm{v}$ navedenih mestih ter preučujemo objavljene primere družbenih in prostorskih napetosti, ki jih povzroča mestni turizem. Na podlagi primerljivega modela rabe turističnega prostora $\mathrm{v}$ mestih bomo poskušali pojasniti, zakaj enako število obiskovalcev povzroča več težav v Pragi kot na Dunaju.

\section{Turisti na Dunaju in v Pragi}

Obe mesti pritegneta isto vrsto turistov iz istih držav, pri čemer avstrijsko prestolnico obišče več Avstrijcev, Prago pa več Rusov, Poljakov in Američanov (preglednica 1). Obe sta enako priljubljeni kulturni turistični destinaciji za obisk ob koncu tedna, v zadnjem desetletju pa so obisk olajšale tudi bolǰ̌e in cenejše letalske povezave z njunima letališcema. Ker sta bili v preteklosti obe pomembni središči, imata močan zgodovinski značaj in veljata za značilni srednjeevropski mesti, na čemer gradita tudi večji del svoje turistične ponudbe. Praga je cvetela v obdobju Svetega rimskega cesarstva, zlasti v 14. stoletju pod vladavino Karla IV. in v 16. stoletju pod vladavino Rudolfa II. Dunaj je postal prestolnica Svetega rimskega cesarstva za Prago, v 15. stoletju, vendar je svoj kulturni pomen izgubil med turškimi vojnami v 16. in 17. stoletju. Kot prestolnica Habsburške monarhije in poznejše Avstro-Ogrske je znova zacvetel v 18. in 19. stoletju in svoj pomen ohranil vse do začetka prve svetovne vojne. Mesti sta obe svetovni vojni preživeli skoraj nedotaknjeni in tako ohranili dediščino, ki jo lahko danes dobro tržita. Dunaj se je po drugi svetovni vojni razvijal v stabilnem političnem in gospodarskem okolju, medtem ko je bil položaj Prage bolj zapleten. Na srečo sta bili celovitost ter ohranitev praške zgodovinske mestne pokrajine in znamenitosti pomemben cilj čeških izobražencev od začetka 19. stoletja in tudi med socializmom, saj sta predstavljali in dokazovali češko narodno identiteto (Hoffman in Musil, 1999, in Simpson, 1999). Te konservatorske zamisli je presenetljivo podpiral tudi socialistični gospodarski sistem, saj zaradi centralističnega nadzora 
Preglednica 1: Prihodi turistov na Dunaj in v Prago leta 2012

\begin{tabular}{|c|c|c|c|c|}
\hline mesto & Praga & & Dunaj & \\
\hline $\operatorname{trg}$ & število & skupaj (\%) & število & skupaj (\%) \\
\hline domači & 713.537 & 13,2 & 1.438 .736 & 23,7 \\
\hline Avstrija & 103.725 & 1,9 & & \\
\hline Francija & 226.883 & 4,2 & 154.309 & 2,5 \\
\hline Italija & 293.526 & 5,4 & 268.652 & 4,4 \\
\hline Nemčija & 659.504 & 12,2 & 1.067 .567 & 17,6 \\
\hline Španija & 181.841 & 3,4 & 192.173 & 3,2 \\
\hline Švica & 59.248 & 1,1 & 174.235 & 2,9 \\
\hline Velika Britanija & 295.637 & 5,5 & 207.272 & 3,4 \\
\hline druge zahodnoevropske države & 533.144 & 9,9 & 474.803 & 7,8 \\
\hline Zahodna Evropa & 2.353 .508 & 43,6 & 2.539 .011 & 41,8 \\
\hline Češka & & & 86.152 & 1,4 \\
\hline Madžarska & 74.992 & 1,4 & 86.558 & 1,4 \\
\hline Poljska & 155.154 & 2,9 & 76.181 & 1,3 \\
\hline Rusija & 470.039 & 8,7 & 279.641 & 4,6 \\
\hline države nekdanjega vzhodnega bloka & 418.847 & 7,6 & 286.565 & 4,7 \\
\hline nekdanji vzhodni blok & 1.119 .032 & 20,6 & 815.097 & 13,4 \\
\hline Evropa (tuji skupaj) & 3.472 .540 & 64,0 & 3.354 .108 & 55,0 \\
\hline ZDA in Kanada & 372.145 & 6,9 & 328.646 & 5,0 \\
\hline drugi ameriški trgi & 135.100 & 3,0 & 112.461 & 2,0 \\
\hline Amerika & 507.245 & 9,4 & 441.107 & 7,3 \\
\hline Indija & 20.521 & 0,4 & 26.181 & 0,4 \\
\hline Izrael & 74.096 & 1,4 & 40.286 & 0,7 \\
\hline Japonska & 104.909 & 1,9 & 161.024 & 2,6 \\
\hline Južna Koreja & 78.782 & 1,5 & 60.078 & 1,0 \\
\hline Kitajska & 98.192 & 1,8 & 126.959 & 2,1 \\
\hline drugi azijski trgi & 134.170 & 2,5 & 203.637 & 3,4 \\
\hline Azija & 510.670 & 9,5 & 618.165 & 10,2 \\
\hline Afrika & 28.117 & 0,5 & 30.783 & 0,5 \\
\hline Oceanija & 68.473 & 1,2 & 69.999 & 1,1 \\
\hline drugi trgi & 93.701 & 2,0 & 124.387 & 2,0 \\
\hline skupaj tuji trgi & 4.680 .746 & 86,8 & 4.638 .549 & 76,3 \\
\hline skupaj domači in tuji trgi & 5.394 .283 & 100,0 & 6.077 .285 & 100,0 \\
\hline
\end{tabular}

Vir: TourMIS (2012)

cen in najemnin ni bilo mogoče graditi na območjih v mestnem središču (Cooper in Morpeth, 1998). Zaradi tega se je prvotna srednjeveška in baročna morfologija mesta popolnoma ohranila. Staro mesto (češ. Staré Město), Mala četrt (češ. Malá Strana) in Novo mesto (češ. Nové Mèsto) so bili tako leta 1992 uvrščeni na Unescov seznam svetovne dediščine, medtem ko je bilo središče Dunaja na seznam dodano šele leta 2003.

Glavne razlike v turistični rabi teh dveh zgodovinskih središč so posledica različne urbane morfologije in različnega turističnega razvoja v drugi polovici 20. stoletja.

\subsection{Morfologija dveh zgodovinskih mest}

Obravnavani mesti imata različno morfološko obliko, ki je posledica njune topografije in zgodovinskega urbanističnega razvoja.

Dunajsko staro mestno jedro se nahaja na desnem bregu donavskega kanala. Nekoč ga je obdajalo srednjeveško obzidje, ki so ga med letoma 1860 in 1880 porušili in nadomestili z mestno obvoznico oziroma znamenitim Ringom, ob katerem so nanizane vse glavne monarhične in meščanske zgradbe in ki 


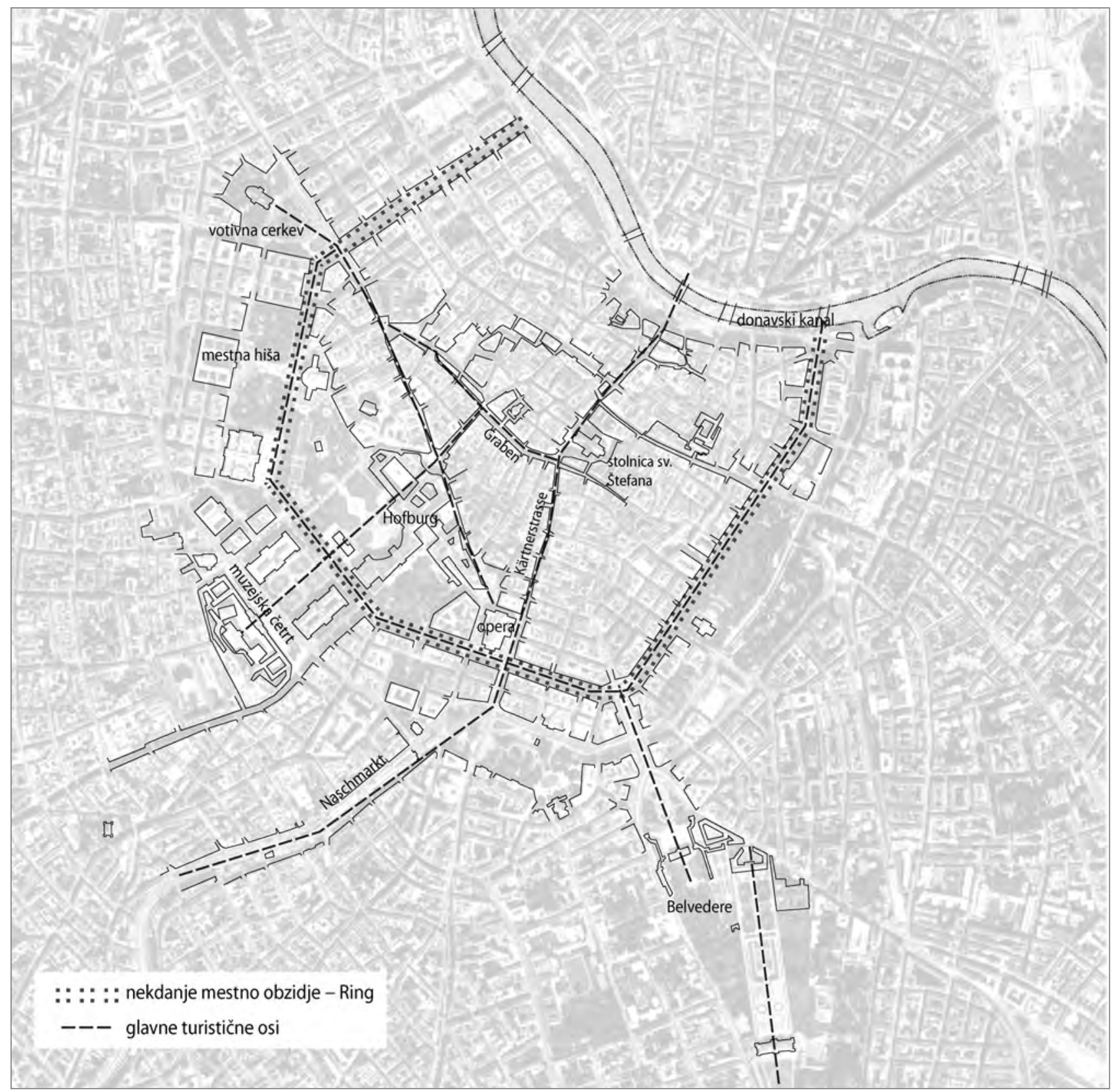

Slika 1: Glavne morfološke in turistične prvine Dunaja

staro mesto povezuje z gosto pozidanimi območji zunaj njega. Srednjeveško mesto je bilo zgrajeno na ruševinah rimskega vojaškega tabora po imenu Vindobona, zaradi česar ima današnji Dunaj geometrično urejene ulice, medtem ko je za središče Prage značilna manj pravilna razporeditev ulic, ki se je razvila v srednjem veku. V središč Dunaja stoji stolnica svetega Štefana, ki je z mrežo ulic, rezerviranih za pešce, povezana z vsemi največjimi mestnimi znamenitostmi znotraj obvoznice. Z obvoznice lahko v mestno jedro vstopimo mimo opere ali čez Trg herojev (nem. Heldenplatz) zraven cesarskega dvora Hofburg, v katerem so nekdaj živeli habsburški vladarji. Nekatere znamenitosti lahko najdemo tudi zunaj obvoznice, na primer tržnico Naschmarkt ter palači Belvedere in Schönbrunn. Poleg teh zanimivosti je bilo v zadnjem času ob donavskem kana- lu in v muzejski četrti v prostorih nekdanjih dvornih hlevov zraven palače Hofburg urejeno tudi nekaj novih turističnih kompleksov.

V nasprotju z Dunajem je razvoj Prage potekal naravneje, nanj pa je vplivala predvsem topografija. Ceprav je bila Praga manjša in je imela manj prebivalcev kot Dunaj, je imela v srednjem veku večje mestno jedro, ki so ga sestavljala štiri mesta na obeh straneh Vltave. Na levem bregu reke je ureditev ulic določala predvsem hribovita pokrajina grajskega okrožja Hradčanov in Male četrti. Na manj hribovitem desnem bregu pa so Staro mesto in predel Josefov ali židovsko četrt obkrožali bregovi Vltave in polkrožna cesta, ki so jo zgradili leta 1871 na mestu nekdanjega baročnega mestnega obzidja. Čeprav ob praški ob- 


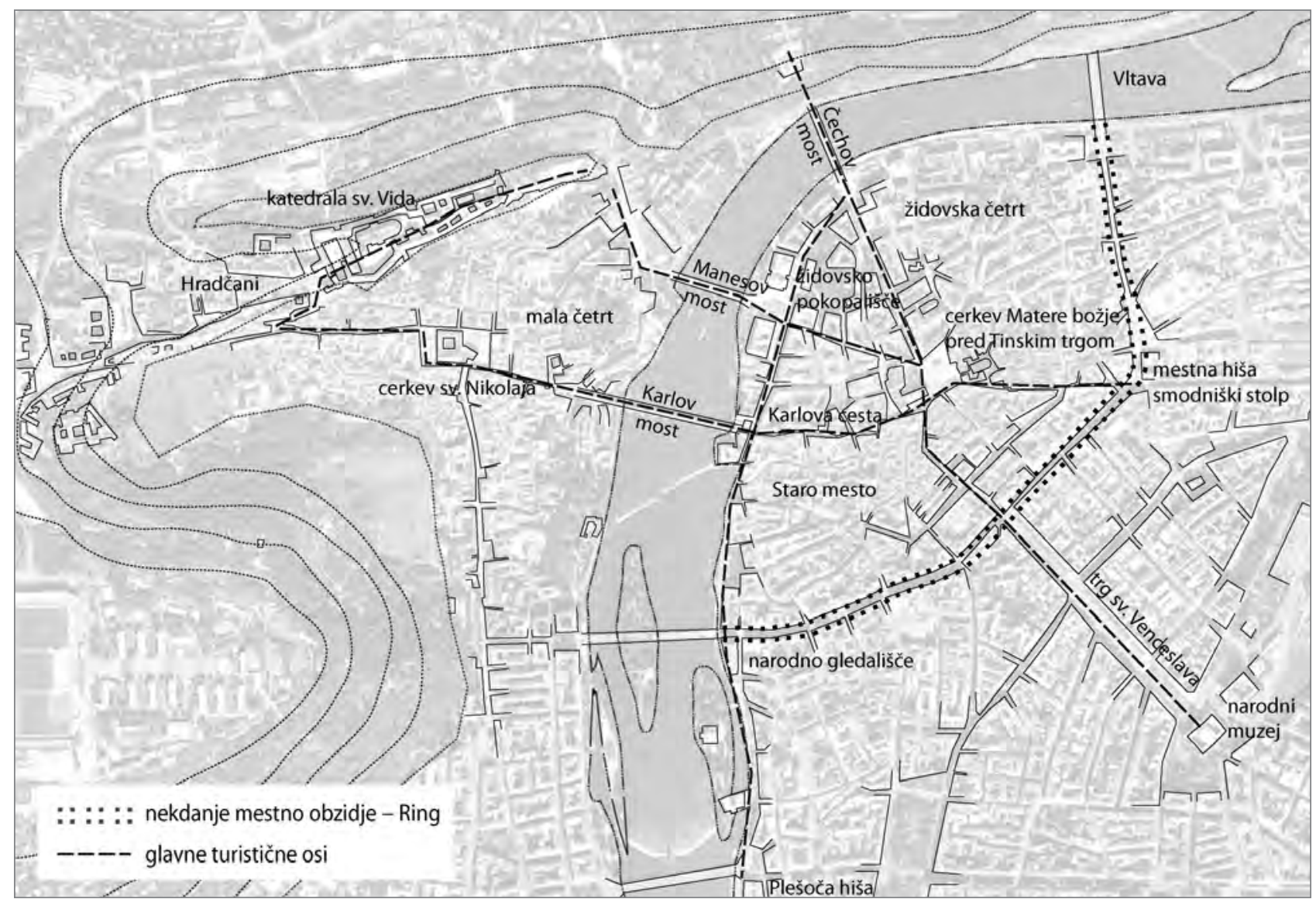

Slika 2: Glavne morfološke in turistične prvine Prage

voznici stojijo narodno gledališče, smodniški stolp in mestna hiša, ta pa je obenem tudi izhodišč za trg svetega Venceslava, se po pretoku turistov ne more kosati z dunajsko.

V Pragi večina obiskovalcev uporablja tri pomembne zgodovinske osi. Karlova ulica (del nekdanje Kraljeve poti) je najstarejša ulica, ki je bila zgrajena v srednjem veku in mestno hišo v Starem mestu povezuje z Malo četrtjo in grajskim kompleksom Hradčani. Z nje lahko dosežemo vse pomembne turistične znamenitosti na levem bregu Vltave: Mostna vrata, cerkev svetega Nikolaja, kraljevo palačo, katedralo svetega Vida in Zlato ulico. Drugo os sestavljata urbani kompoziciji iz 19. stoletja: 750 metrov dolg trg svetega Venceslava, ki se končuje z narodnim muzejem na majhnem hribu, in Pariška ulica, ki se končuje $s$ Čechovim mostom in hribom z obsežnim parkom na drugi strani reke. Tretjo os tvori reka Vltava, ki povezuje vse glavne mestne zanimivosti. V okviru urbanističnega načrtovanja v 19. in 20. stoletju so bile nekatere pomembne ustanove zgrajene na rečnem bregu, na katerem lahko turisti uživajo v lepih razgledih ter obiščejo gledališča, koncertne dvorane in muzeje.

Dunaj ima jasno morfološko zgradbo brez večjih topoloških omejitev, Praga pa ima bolj zapleteno morfologijo, saj se na njenem območju stikajo štiri srednjeveška mesta, na ureditev ulic pa vplivajo tudi hribovita pokrajina in rečni bregovi.

\subsection{Zgodovinski razvoj turizma}

V EU imajo samo Pariz, Berlin, Rim, Barcelona in Madrid več turističnih prihodov kot Dunaj, ki jih beleži 6.077.285, in Praga, ki jih beleži 5.394.283 (TourMIS, 2012). Pred drugo svetovno vojno sta imeli obe mesti podoben zgodovinski razvoj in podobno število turistov, Praga pa je kot turistična destinacija Dunaj ponovno ujela po padcu železne zavese.

Med drugo svetovno vojno je bil turizem močno okrnjen, pred tem pa sta obe mesti pritegovali podobno število turistov. Med letoma 1925 in 1935 je Dunaj vsako leto obiskalo približno pol milijona turistov oziroma tudi do 700.000 turistov, vendar je leta 1933 to število padlo pod 400.000, ker je Nemčija za svoje državljane uvedla gospodarsko sankcijo, in sicer so morali za vsako potovanje v Avstrijo plačati tisoč takratnih nemških mark (avstrijski statistični urad, 1938). V istem obdobju se je v Pragi število turistov s 300.000 povečalo na več kot 600.000 na leto, z rahlim upadom med letoma 1933 in 1934 (češkoslovaški statistični urad, 1938).

Za oba kraja obstaja le malo statističnih podatkov za čas med drugo svetovno vojno in takoj po njej. V Pragi je po vojni železna zavesa učinkovito preprečila razcvet turizma, ki je bil značilen za države Zahodne Evrope. Pomembno je, da razume- 


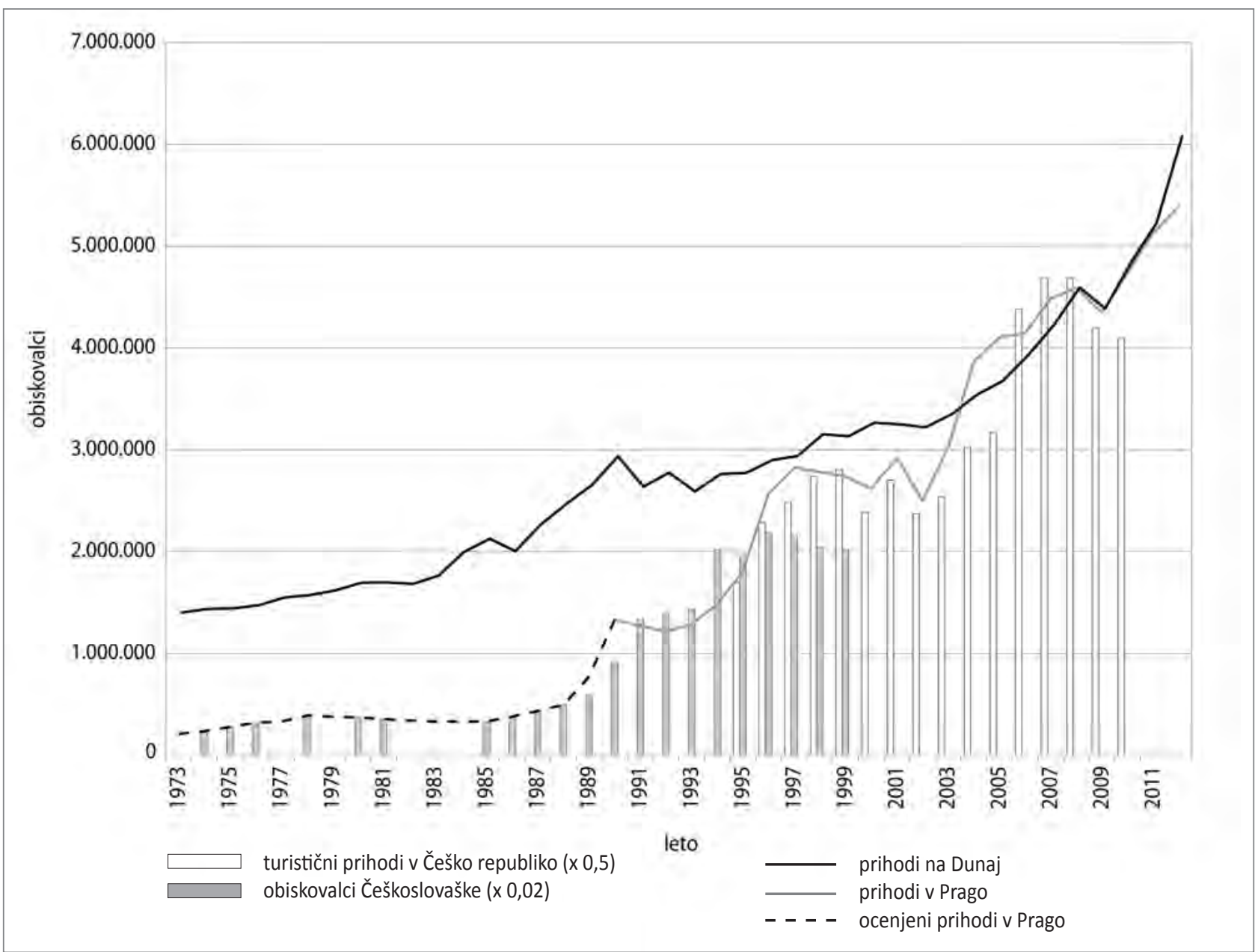

Slika 3: Turistični prihodi v Prago in na Dunaj med letoma 1973 in 2011 (vir: Franke, 1984; Medlik, 1990; Maxwell, 1995; Hoffman in Musil, 2009, in TourMIS, 2012).

mo razliko med enakomernim razvojem turizma v Pragi in na Dunaju ter nenadnim povečanjem števila turistov po obdobju zaprtja v povojnem obdobju. Število turističnih prihodov med obema mestoma je izredno težko primerjati, saj so statistični podatki za Prago na voljo samo od leta 1991, medtem ko sta avstrijska turistična organizacija in avstrijski statistični urad te podatke zbirala vse od leta 1955. Za čas pred letom 1991 je za Prago na voljo samo nekaj splošnih statističnih podatkov o prihodih na Češkoslovaško in posteljnih zmogljivostih brez podatkov o dejanski zasedenosti (Franke, 1984). S tem pomanjkanjem podatkov so se spopadali tudi drugi raziskovalci, ki so preučevali turizem na Češkoslovaškem in v Pragi (Medlik, 1990; Maxwell, 1995, ter Hoffman in Musil, 2009). Njihove izsledke in razpoložljive statistične podatke (TourMIS, 2012) smo uporabili za primerjavo turističnih prihodov na Dunaj in v Prago, kar je prikazano na sliki 3. Na tej sliki so prikazani tudi razpoložljivi podatki o številu turističnih prihodov v Češko republiko, pri čemer lahko vidimo povezavo med številom prihodov $\mathrm{v}$ državo in številom prihodov $\mathrm{v}$ prestolnico, na podlagi česar smo ocenili pretekle manjkajoče vrednosti prihodov v Prago.
Dunaj je lahko v zadnjih 50 letih enakomerno razvijal svojo turistično infrastrukturo, pri čemer je ohranjal identiteto središča klasične glasbe in varuha habsburške dediščine po vojni. Avstrija je svojo neodvisnost ponovno dobila leta 1955, ko so jo zapustile zavezniške enote. Istega leta je bila na podlagi posebnega zakona o turizmu na Dunaju ustanovljena dunajska turistična organizacija (prvotno dunajsko turistično društvo). $S$ tem ni bilo uvedeno samo neodvisno strokovno vodenje in urejanje dunajskega turizma, ampak tudi učinkovito pobiranje davkov in prerazporeditev prihodkov iz hotelske dejavnosti. Leta 1955 je bilo na Dunaju zabeleženo 1,6 milijona nočitev, to število pa je z leti enakomerno naraščalo: leta 1964 je doseglo 3 milijone, leta 19754 milijone, v 80 letih 20. stoletja od 5 do 6 milijonov, v 90. letih približno 7 milijonov in leta 2011 12,3 milijona. Turizem je pomemben vir prihodka za Avstrijo, ki od konca druge svetovne vojne velja za vojaško nevtralno državo, v kateri se lahko vsi turistični déležniki razvijajo v stabilnem gospodarskem in političnem okolju (TourMIS, 2012).

Praga je bila del vzhodnega bloka in zato se ni mogla razvijati na podoben način kot Dunaj. S češkoslovaškim državnim 
udarom leta 1948 je mesto postalo del Sovjetske zveze in tako izgubilo velik del svojih turistov. Vsi hoteli in storitve so bili nacionalizirani, meje so se zaprle in potovanje je bilo omejeno. Vsak tujec je za vstop v državo potreboval vizum, zaradi birokracije in odkrite sovražnosti do kapitalizma pa so turisti iz Zahodne Evrope le stežka vstopili v Češkoslovaško republiko. V 60. letih 20. stoletja je vlada prepoznala prednosti prihoda zahodnjaških turistov, ki bi v državi zapravljali v trdi valuti, toda čeprav se je število tujih gostov z manj kot 5 milijonov v 60. letih 20. stoletja povečalo na skoraj 19 milijonov leta 1986 , je več kot $90 \%$ turistov prihajalo iz držav vzhodnega bloka (Maxwell, 1995). Vse to pa se je korenito spremenilo po žametni revoluciji leta 1989. Takrat so gostje iz postsocialističnih držav zaradi recesije v prvih letih liberalizacije skoraj popolnoma izginili, lepote prej zaprtega mesta pa so začeli odkrivati novi turisti z Zahoda. Med letoma 1989 in 1993 sta se ta procesa nekako uravnotežila, kar je povzročilo stagnacijo števila turistov, ki je skokovito naraslo šele po letu 1993. Eksotičnost postkomunističnega mesta je hitro zbledela, poleg tega je primanjkovalo tudi kakovostne infrastrukture in hotelov, ki bi pritegnili več turistov iz bogatejših držav (Maxwell, 1995). Zaradi tega je med letoma 1997 in 2002 prišlo do ponovne stagnacije. Od 90. let 20. stoletja je prednostna naloga v Pragi temeljita obnova mestnega središča in s pomočjo tujega kapitala je bilo odprto veliko novih hotelov. Leta 1990 je bilo v Pragi na voljo 15.000 postelj, kar je bilo samo dvakrat več kot v 70. letih 20. stoletja. Śtevilo je leta 1996 naraslo na 38.699 in na začetku novega tisočletja doseglo 50.000 (Hoffman in $\mathrm{Mu}-$ sil, 2009). Po letu 2002 sta intenzivna gradnja infrastrukture in prihod nizkocenovnih letalskih družb v prestolnico Češke republike povzročila ponovno skokovito povečanje turističnih prihodov. Praga je svojega tekmeca po številu nočitev prehitela že leta 1997, po številu turističnih prihodov pa leta 2004. Danes v Pragi nič več ne spominja na obdobje komunizma, saj se je mesto razvilo v dobro ohranjeno in predstavljeno urbano zakladnico s sodobno hotelsko dejavnostjo in storitvami.

V zadnjih letih pa je Dunaj Prago ponovno dohitel. Med letoma 2008 in 2010 sta imeli mesti enako število turističnih prihodov, trenutno pa ima Dunaj celo rahlo prednost, Prago pa dohiteva tudi po številu nočitev. Pred padcem železne zavese je Dunaj obiskalo petkrat več turistov kot Prago, z odprtjem mej pa jih je avstrijska prestolnica veliko izgubila. Določeno število turistov iz Zahodne Evrope se je raje odločalo za nove destinacije v novoodprtih zahodnoevropskih mestih, izgubila pa je tudi določeno število turistov iz vzhodnoevropskih držav, ki so bile zdaj v recesiji. Sredi 80 . let 20. stoletja je samo z Madžarske letno prihajalo več kot 150.000 obiskovalcev, ta številka pa je sredi 90. let padla na približno 30.000. Prebivalci držav vzhodnega bloka so pred koncem komunizma v Avstrijo prihajali kupovat blago, ki ni bilo dostopno za železno zaveso. $\mathrm{Z}$ uvedbo zahodnjaških političnih sistemov so ti obiski postali redki, na začetku 90. let pa se je v postsocialističnih državah začelo tudi obdobje gospodarske recesije, ki je ustavilo vsakršno obliko potovanj. Da bi povečali število obiskovalcev, so po letu 2000 na Dunaju izboljšali in dodatno razvejili svojo turistično in kulturno ponudbo. Leta 2001 so odprli novo muzejsko četrt (nem. Museumsquartier, v nadaljevanju: MQ), leta 2008 so obnovili in ponovno odprli muzej Albertina, poleg tega pa so v mestu opravili še mnoge druge manjše posege (Frantz, 2005). Dunajska turistična organizacija je tako lahko izpolnila zadani cilj več kot 10 milijonov nočitev do leta 2010, kar je bilo veliko več kot v začetku desetletja. Če se bo ta razvoj nadaljeval, bo to dokaz, da je načrtovani model turističnega razvoja Dunaja trajnejši kot nenačrtovana liberalizacija turizma v Pragi, ki negativno vpliva na to, kako obiskovalci in tudi domačini dojemajo mesto.

\subsection{Vpliv turizma}

Medtem ko turizem na gospodarski ravni blagodejno vpliva na obe mesti, enako število turistov različno vpliva na družabno in urbano življenje njunih prebivalcev.

Mednarodno svetovalno podjetje Mercer je leta 2012 Dunaj že četrto leto zapored izbralo za mesto z najvišjo kakovostjo življenja na svetu. Podjetje v raziskavi kakovosti življenja upošteva več meril, ki določajo mesto z visoko kakovostjo življenja, in Praga je na njihovem seznamu šele na 69. mestu. Poleg tega je Dunaj zasedel drugo mesto v podobni raziskavi o kakovosti življenja v mestih, ki jo izvaja podjetje Economist Intelligence Unit. Praga je na njegovem seznamu šele na 60. mestu. $\mathrm{V}$ teh pogledih vpliv turizma ni obsežen, ker pa rekreativna in kulturna ponudba močno vplivata na kakovost življenja $\mathrm{v}$ mestu, je treba opozoriti na to, da so turisti zavzeli najlepše in najdragocenejše predele češkega glavnega mesta ter lokalne prebivalce izrinili s srednjeveških trgov in skoraj vseh območij okrog glavnih kulturnih znamenitosti.

To se na Dunaju ni zgodilo. V mestu so nekatera zgodovinska območja namenjena izključno turistom; na primer območja, ki najbolje ponazarjajo oglaševana slogana » prestolnica Habsburžanov« in »prestolnica glasbe «. Vsa javna območja med temi znamenitostmi pa nudijo različne storitve tako za turiste kot tudi za domačine. Novejše razširitve turističnega omrežja so bile načrtovane kot večfunkcijska okolja, ki ponujajo veliko storitev tudi za domačine. Na primer nova muzejska četrt MQ, ki zaokroža glavno turistično os cesarskega dvora Hofburg, je obenem priljubljena točka, na kateri se zbirajo mladi Dunajčani; premično pohištvo, oblikovano za ta prostor, dodatno krepi to funkcijo mestnega zbirališča. Prenova območja je bila načrtovana vse od leta 1977, vendar je počasnemu procesu projektiranja vselej sledila obsežna razprava, posledica katere so bili stalni kompromisi in spremembe, vse dokler ni bil leta 2001 


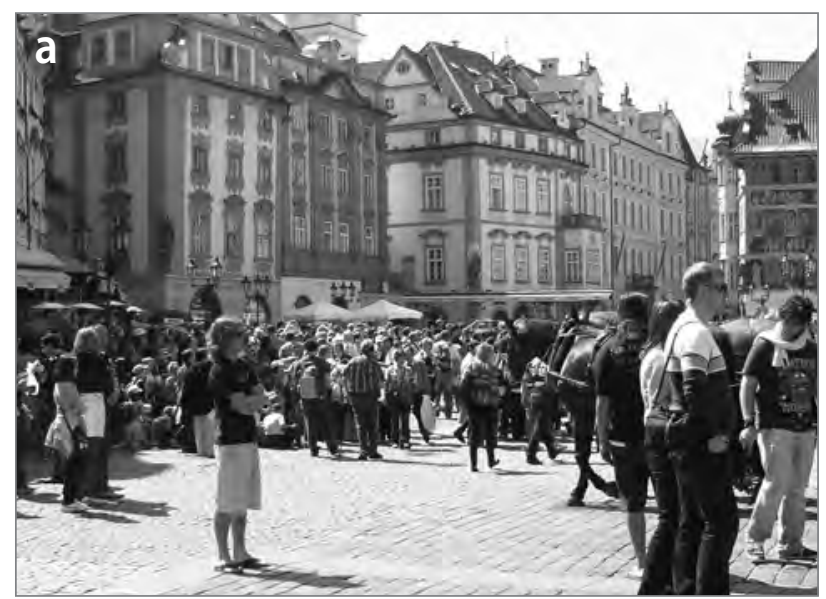

Slika 4: (a) Zgoščanje turistov v starem praškem mestnem jedru; (b) ulica Graben na Dunaju, glavna cona za pešce v starem mestnem jedru (foto: (a) Bálint Kádár, (b) Alex Diem).

kompleks končno odprt (Frantz, 2005). Z načrtnim razvojem brega donavskega kanala, na katerem se stikata turistični in poslovni del mesta, so bili zgrajeni in urejeni različni objekti za poslovno rabo in prosti čas. Območje je postalo živahno središč z novimi bari, rečnim pristaniščem in umetnimi plažami, ki jih uporabljajo turisti in domačini (Hatz, 2008). Središče Dunaja velja za vrhunsko stanovanjsko okolje, v katerem se skrbno načrtovana turistična območja izmenjujejo s storitvami za lokalne prebivalce.

Na drugi strani se je raba starega mestnega jedra v Pragi izrazito spreminjala, zaradi česar ni bilo časa za izvedbo celovitega načrtovanja. Po padcu železne zavese so obsežna privatizacija, ponovna privatizacija in sprostitev trga povzročile hitre spremembe v rabi zemljišč v središču mesta (glej Tsenkova, 2011). Najdonosnejša raba zemljišč je bila povezana s turizmom, storitve za vse večje število turistov pa so se zgoščale okrog glavnih znamenitosti. Stanovanjske stavbe v središču so bile predelane $\mathrm{v}$ hotele in večina objektov tik ob ulici se je spremenila $\mathrm{v}$ bare, restavracije in trgovine $s$ spominki, s čimer se je nekoč bogato kulturno, trgovsko in stanovanjsko urbano tkivo spremenilo $\mathrm{v}$ enofunkcijsko turistično okolje (Cooper in Morpeth, 1998). Manjkala je strokovna ali družbena volja za usmerjanje prostorske in gospodarske ureditve rastoče turistične dejavnosti, saj je centralizirano načrtovanje veljalo za komunistično metodo. Čeprav so leta 1996 sprejeli celovit strateški načrt za Prago, je bilo urbanistično načrtovanje v večji meri zanemarjeno (glej Tsenkova, 2011). Vse to je v mestnem središču hitro privedlo do družbeno-gospodarske napetosti, o čemer so pisali mnogi raziskovalci (Maxwell, 1995; Cooper in Morpeth, 1998; Hoffman in Musil, 1999; Simpson, 1999, in Deichmann, 2002). Najočitnejša posledica tega je bil hiter padec števila lokalnih prebivalcev v središču mesta (Ourednicek in Temelová, 2009), ki je bil najopaznejši okrog Kraljeve poti, to je zaporedja prenapolnjenih ulic, ki povezujejo vse glavne mestne znamenitosti (Simpson, 1999). Turisti so popolnoma zavzeli mesto, kar je pritegnilo pozornost mnogih turističnih

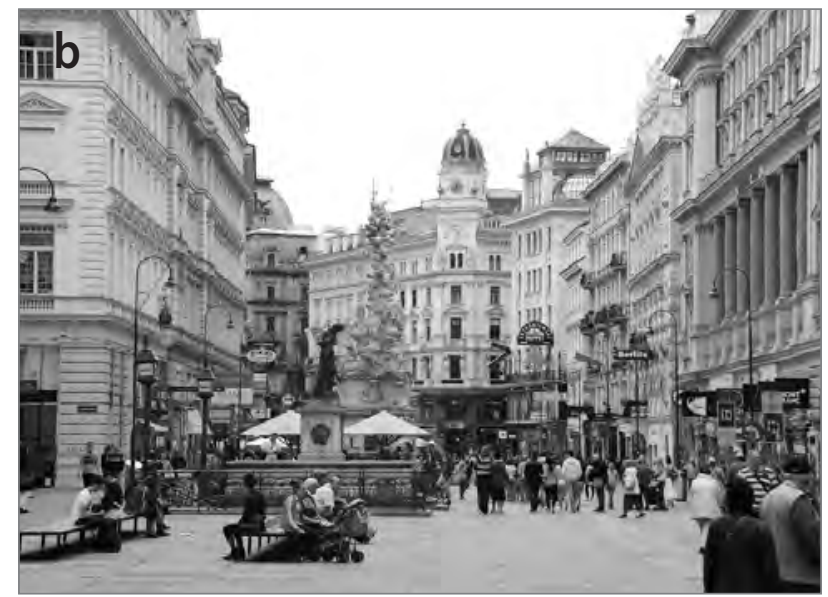

strokovnjakov, in tako je nastal prej omenjeni seznam literature o problemih v mestu, povezanih s turizmom. Do tega na Dunaju ni prišlo.

\section{Primerjava prostorskih vzorcev mestnega turizma}

Na podlagi razumevanja, zakaj enako število turistov povzroča očitne težave v Pragi, na Dunaju pa ne, lahko pridemo do pomembnih urbanističnih ugotovitev, s katerimi lahko dosežemo popolno ravnotežje med turizmom in lokalnim življenjem. Prostorska razporeditev enakega števila turistov v teh dveh urbanih središčih se močno razlikuje in družbeno-gospodarski problemi, povezani s turizmom, naj bi bili manj verjetni v enakomernejšem omrežju turističnih poti in znamenitosti. Zaradi zgodovinske in topografsko pravilnejše urbanistične mreže je na Dunaju razporeditev turistov enakomernejša, poleg tega pa se uravnava tudi s skrbnim načrtovanjem turistične infrastrukture in rabe zemljišč. V Pragi je srednjeveška urbanistična mreža omejena z reko in s strmimi hribi, znotraj nje pa je bila v zadnjih letih turistična infrastruktura zgrajena na podlagi potreb in ne urbanističnega načrtovanja.

Da bi lahko dokazali, da je razporeditev turistov na Dunaju enakomernejša kot v Pragi, potrebujemo ustrezno metodo.

\subsection{Zbiranje podatkov o turistični rabi urbanega prostora}

Zaradi pomanjkanja primerljivih modelov mestnega turizma je tovrstne ugotovitve težko dokazati. Turisti mestno okolje uporabljajo podobno kot drugi uporabniki, zaradi česar je težko izmeriti njihovo gibanje in rabo zemljišč. Po mnenju Charlesa A. Stansfielda (1964) mestnega turizma ne moremo izmeriti, zaradi česar ga raziskovalci zanemarjajo in se raje poglabljajo $\mathrm{v}$ podežlski turizem, ki je lažje merljiv. $\mathrm{V}$ zadnjih desetletjih 


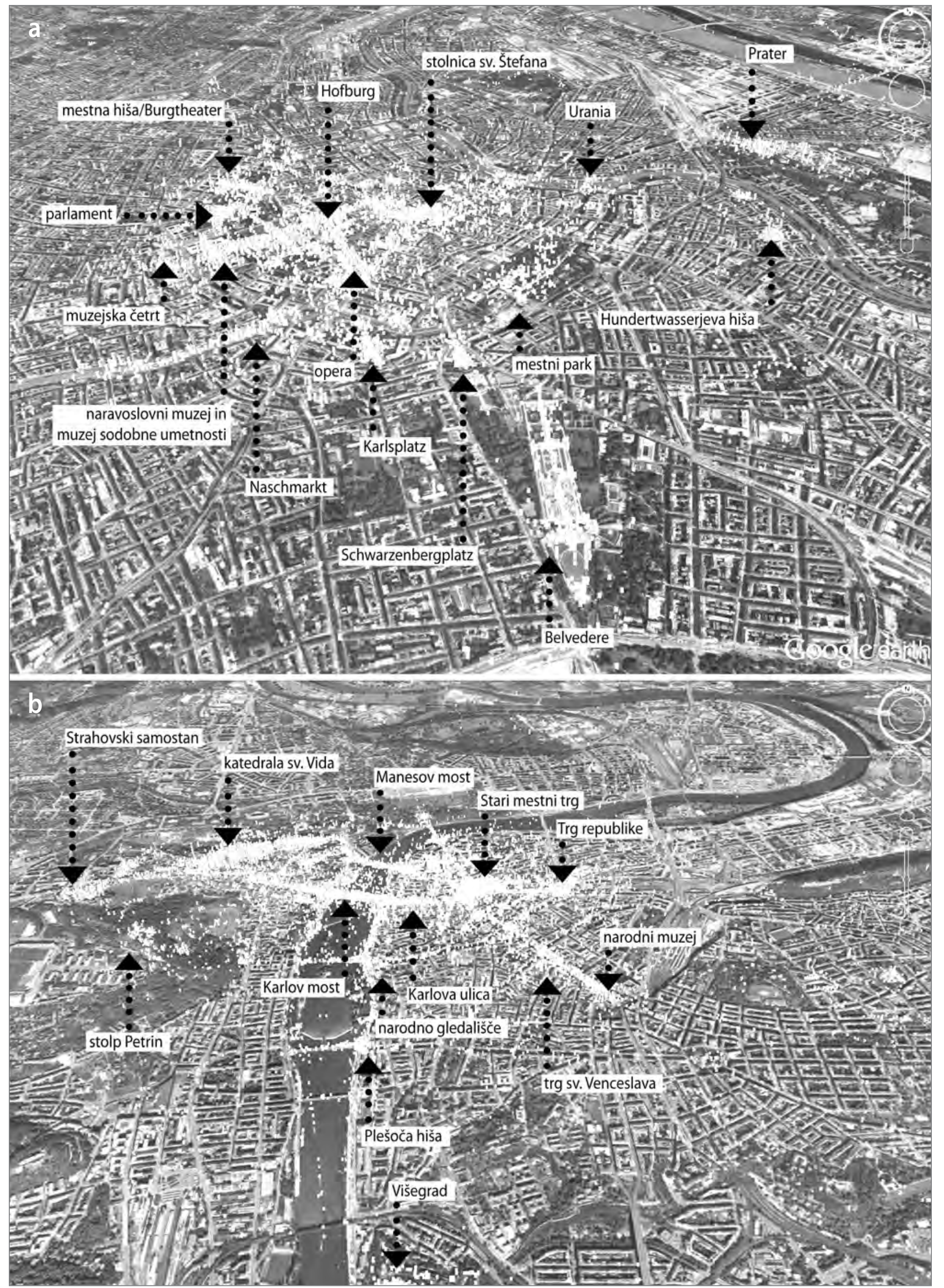

Slika 5: Lokacije geografsko označenih fotografij v središču (a) Dunaja in (b) Prage 
je bil narejen napredek v določanju prostorskih vzorcev dejavnosti turistov in mnogi raziskovalci so poskušali izboljšati osnovni model mestnega turizma, ki sta ga leta 1990 v članku The tourist-historic city (Turistično zgodovinsko mesto) razvila Gregory Ashworth in John E. Turnbridge.

$\mathrm{Na}$ podlagi klasične metode uporabe vprašalnikov in časovno-prostorskih dnevnikov, ki so jih izpolnjevali turisti, so bili zbrani podatki o pogledih obiskovalcev na urbani prostor: Bob McKercher in Gigi Lau (2008) sta analizirala gibalne vzorce turistov in določila 11 slogov gibanja; Noam Shoval in Adi Raveh (2004) sta kategorizirala skupke znamenitosti v Jeruzalemu, ki so jih obiskali turisti z različnimi lastnostmi; Bruce Hayllar in Tony Griffin (2005) sta določila glavne izkušnje turistov, povezane $s$ fizičnim okoljem in z vzdušjem starega mestnega jedra The Rocks v Sydneyju. Uporaba sistema globalnega pozicioniranja (GPS) in mobilnih telefonov za sledenje turistom je omogočila natančnejše meritve gibanja turistov, $s$ katerimi lahko določimo vzorce v času in prostoru (Shoval in Isaacson, 2010). Marko Modsching idr. (2008) so podatke, zbrane s sistemom GPS, uporabili za določitev najbolj obiskanih območij in poti v nemškem mestu Görlitz. Te metode so raziskovalcem omogočile, da so zbrali in analizirali natančne podatke o prostorskem vedênju turistov. Vse opisane raziskave so postregle z izsledki o tem, kako se posamezen turist premika v urbanem okolju, nobena od njih pa ni zagotovila kvantitativnih podatkov o tem, kako turisti uporabljajo prostor. $\mathrm{Na}$ drugi strani pa tudi klasične oblike zbiranja turističnih statističnih podatkov ne merijo števila obiskovalcev, ki se premika po prostih javnih krajih $\mathrm{v}$ določenem mestu. Vsi razpoložljivi statistični podatki temeljijo na številu prodanih vstopnic in obiskovalcev posameznih znamenitosti, ne upoštevajo pa dejstva, da večina turistov ne obišče veliko teh prizoriščc, temveč jih fotografira med sprehajanjem po mestu.

Turistično rabo prostora bi lahko določili $z$ analizo in s pozicioniranjem fotografij, ki jih naredijo turisti. V mestnem turizmu so spomeniki, razgledne točke in prizorišča različnih dogodkov glavni predmet potrošnje. $\mathrm{Na}$ teh krajih turisti fotografirajo sami sebe in tako obeležijo svoj obisk, s čimer dokončno dokažejo, da so zares doživeli mesto (Urry, 1990). Čeprav so za Johnom Urryjem vlogo fotografij turistov pri doživljanju mesta analizirali mnogi strokovnjaki (Jenkins, 2003; Larsen, 2006, in Garrod, 2009), je oblikovanje statističnih podatkov na podlagi fotografij velikega števila turistov šele v povojih. Danes ljudje veliko fotografij z natančnimi geografskimi podatki objavijo na družbenih omrežjih, kot sta Panoramio.com in Flickr. com. Motivacija turistov, da zabeležijo in delijo svoje osebne izkušnje s svojimi fotografijami se dobro sklada z možnostmi, ki jih nudijo tovrstne spletne storitve. Z geografskim označevanjem (ang. geotagging) teh fotografij lahko turisti posnet- ke povežejo z dejanskimi kraji na zemljevidu sveta. Nekateri fotografski aparati, vključno z vse večjim številom pametnih telefonov, imajo vgrajen sistem GPS, ki omogoča samodejno geografsko označevanje, tovrstne spletne strani pa omogočajo tudi ročno umeščanje posnetkov na zemljevid (Gede, 2012). Natančno geografsko označeni posnetki kažejo vzorec, ki daje realne podatke o številu obiskovalcev.

Flickr.com (http://www.flickr.com) ima danes že več kot 175 milijonov geografsko označenih posnetkov, med drugim tudi približno 400.000 na Dunaju in 400.000 v Pragi. $S$ programskim vmesnikom API lahko vse te posnetke tudi analiziramo. Nekatere novejše raziskave preučujejo vsebino in besedne označbe teh fotografij in jih povezujejo z geografsko lokacijo (Hollenstein in Purves, 2010, ter Pang idr., 2011). Druge preučujejo posamične znamenitosti in rekonstruirajo vidne podatke o spomenikih (Ji idr., 2011, ter Crandall in Snavely, 2012). Iz teh podatkovnih zbirk pa je bilo pridobljeno le malo kvantitativnih turističnih podatkov. Izjema sta raziskavi, ki sta analizirali fotografije Firenc, objavljene na Flickr.com med letoma 2005 in 2007 (Girardin idr., 2008), in fotografije Budimpešte (Gede, 2012). Mátyás Gede je na podlagi števila geografsko označenih fotografij izdelal diagrame in točke zanimivosti označil na Google Earth. S to metodo lahko ločimo fotografije uporabnikov, ki živijo na preučevanem območju in objavljajo posnetke v različnih časovnih obdobjih (domačini), in fotografije uporabnikov, ki zunaj določenega časovnega okvira niso objavili fotografij tega mesta (turisti). Predstavitve in podatkovne zbirke, ki jih je razvil Mátyás Gede, smo v tej raziskavi uporabili za pridobitev podatkov o Dunaju (slika 5a) in Pragi (slika 5b) med letoma 2000 in 2011.

Poudariti je treba, da uporabniki spletnih strani, ki omogočajo objavo posnetkov, predstavljajo le majhen del vseh obiskovalcev. Raziskave potrjujejo, da večina turistov na svojih potovanjih fotografira. Raziskava, ki jo je med 1.466 gospodinjstvi v Hongkongu izvedla hongkonška visoka šola za hotelirstvo in turistični menedžment ter se je osredotočala na fotografije turistov in rabo družbenih medijev za njihovo objavo (Lo idr., 2011), je pokazala, da je $89 \%$ anketiranih turistov na potovanju fotografiralo. Od tega jih je 41,4\% nekaj fotografij objavilo na spletu, $16,5 \%$ pa jih je to storilo na spletnih straneh, kot je Flickr.com. Raziskava je razkrila močno povezavo med starostjo in izobrazbo turistov ter njihovo pripravljenostjo, da slike objavijo na spletu. Oded Nov in Čen Ye (2010) sta potrdila, da je skupina turistov, ki slike s potovanj objavlja na strani Flickr. com, nadpovprečno izobražena in stara okrog 33 let. Veliko število objavljenih geografsko označenih fotografij je lahko dobro statistično orodje, $s$ katerim lahko potrdimo turistično rabo prostora, čeprav so stareǰ̌e generacije pri tem slabše zastopane. 


\subsection{Grafični prikaz turistične rabe prostora}

$\mathrm{Z}$ uporabo zemljevidov, izdelanih $s$ pomočjo podatkovnih zbirk spletne strani Flickr.com, lahko izdelamo matematični graf, ki prikazuje turistično rabo prostora $\mathrm{v}$ mestih. $\mathrm{V}$ eni od svojih prejšnjih raziskav sem tak graf izdelal na podlagi objavljenih fotografij, posnetih na Dunaju, v Pragi in Budimpešti, pri čemer sem analiziral spremembe turistične rabe $\mathrm{v}$ zadnjih 20 letih (Kádár, 2012). V tem članku so tovrstni podatki uporabljeni za primerjavo sedanjih turističnih sistemov na Dunaju in v Pragi. Ni nujno, da vozlišča na teh grafih predstavljajo posamezne znamenitosti, ampak označujejo predvsem neprekinjene javne prostore, na katerih lahko turisti obiščejo in fotografirajo znamenitosti, ne da bi se pomikali naprej. Pokrivajo lokacije najpomembnejših znamenitosti, ki jih priporočajo turistični vodiči, njihovi robovi pa predstavljajo glavne turistične

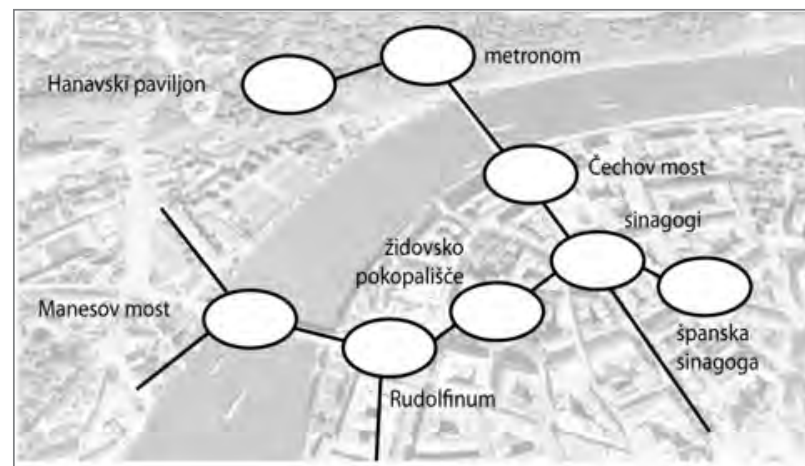

3. Pretvorba $v$ vozlišča in robove

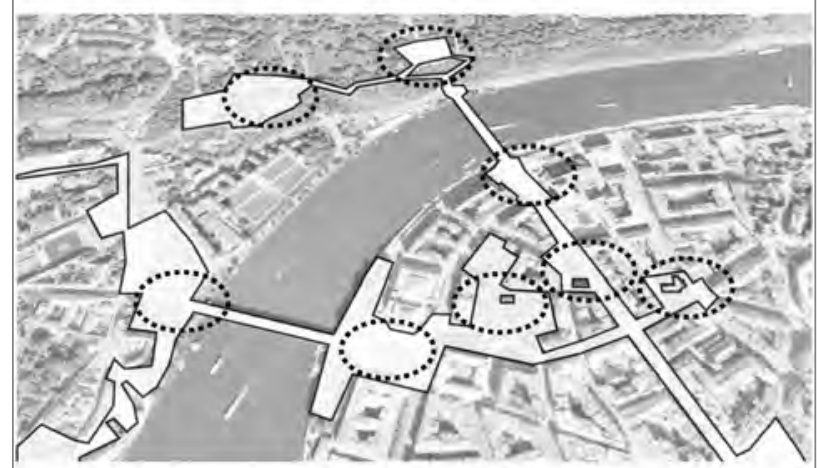

2. Razporeditev javnih prostorov, ki jih uporabljajo turisti

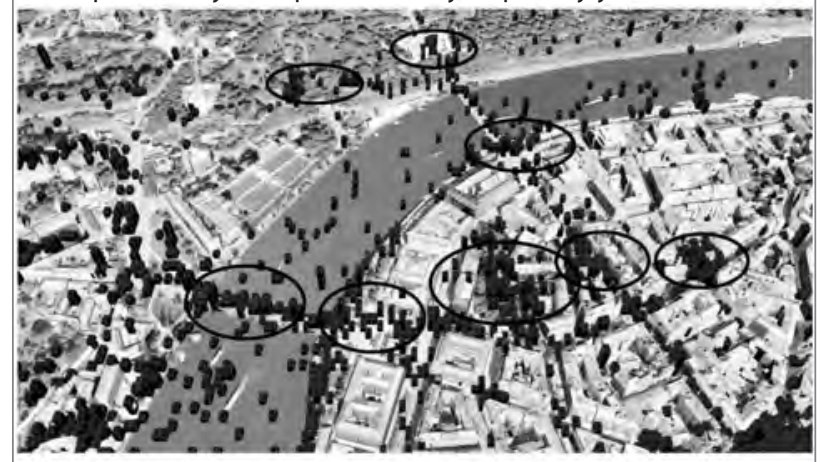

1. Določitev turističnih vozlišč

Slika 6: Oblikovanje matematičnih grafov turistične rabe prostora na podlagi zemljevidov, izdelanih s pomočjo geografsko označenih fotografij poti med temi znamenitostmi, pri katerih gre večinoma za cone za pešce (slika 6). Za oblikovanje tovrstnih grafov je pomembno poznavanje sistema javnih prostorov v mestih. Samo poti, rezervirane za pešce, lahko predstavljajo robove, ki povezujejo glavne znamenitosti. Oblike motoriziranega prevoza med turističnimi zanimivostmi niso upoštevane, saj med uporabo javnega prometa ali turističnih avtobusov turisti niso prisotni na javnih krajih, ne povzročajo gneče in ne uporabljajo drugih uličnih storitev.

Uporaba grafov za opisovanje urbanih prostorov ni nova metoda. S starejšimi deli, ki opisujejo človeško rabo in dojemanje mest z mrežnim prikazom, lahko preverimo veljavnost izbrane primerjalne metode. Kevin Lynch (1960) je v svojem slavnem delu The Image of the City (Podoba mesta) opredelil pet prvin, ki jih uporabniki urbanih okolij uporabljajo za opis tega okolja. Mesta imajo različna miselna »okrožja «, v katerih »poti « in » robovi « določajo človeško gibanje, »vozlišča « in »orientacijske točke « pa predstavljajo pomembne kraje. Lynch miselnih zemljevidov ni analiziral v obliki matematične mreže. Šele Christopher Alexander (1965) je v svojem delu A City is Not a Tree (Mesto ni drevo) preučeval naravo urbanih prostorov in funkcij z načeli mreženja. Opozoril je na slabosti drevesne strukture urbanih oblik (to je kadar so funkcije urejene druga za drugo $z$ malo vejami in brez alternativnih poti). Poudaril je polmrežne strukture živih mest, $\mathrm{v}$ katerih so prostori urejeni v mrežo z velikim številom vej, ki se med seboj sekajo. Njegovo delo in matematični pristop $\mathrm{k}$ urbanim strukturam sta navdahnila veliko strokovnjakov, ki so poskušali opisati zapletene mestne mreže. Nikos A. Nikos Salingaros (2004 in 2005) povzema nekatera najpomembnejša načela razbijanja kompleksnosti urbanih sistemov v grafe, ki so sestavljeni iz vozlišč in robov.

Aspa Gospodini (2001) tovrstne grafe uporablja za razlago turistične rabe urbanih prostorov in opredeljuje vlogo urbane morfologije pri zadovoljstvu turistov in gradnji turističnih objektov. Poleg tega opozarja na negativne vplive drevesne strukture in živahnost polmrežne strukture v urbanih prostorih, pri čemer se sklicuje na načelo sočasnih in zaporednih ureditev, ki jih opisuje Henk W. J. Boerwinkel (1995), in poudarja, da so te za turiste privlačnejše, ker nudijo več možnosti za raziskovanje in $s$ tem več svobode, ki je pri prostočasnih dejavnostih zelo pomembna. Gospodini predlaga analizo turističnih mrež z vidika prostorske sintakse, to je metodo analize sistemov prostorske sintakse, ki jo je uvedel Bill Hillier (1996). Pri Hillierjevi metodi gre za pretvorbo arhitekturnega in urbanega prostora $\mathrm{v}$ matematične grafe. Na podlagi analize povezanosti znamenitosti s prostorsko sintakso dobimo številsko formulo sintaktične globine nastalih grafov. Za to potrebujemo samo osnovne izračune globine, ki jih uporabimo za ves graf. Ocena grafov za Prago in Dunaj temelji na izračunih prostor- 


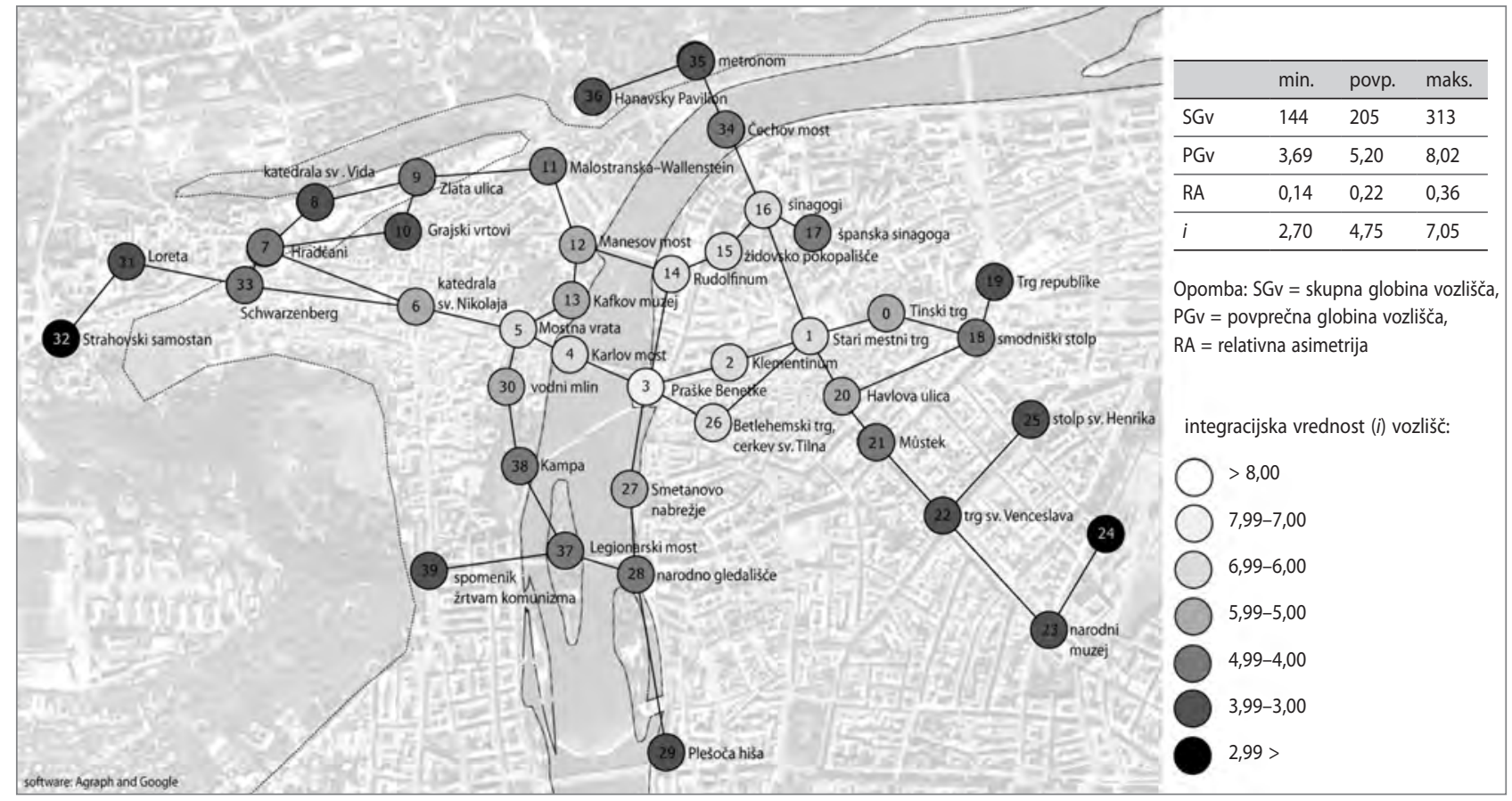

Slika 7: Sistem turističnega prostora za pešce v Pragi leta 2011

ske sintakse v obliki vozlišč, izdelanih s programom Agraph. Za primerjavo grafov uporabimo integracijsko vrednost $i$, ki jo program Agraph izračuna iz povprečne globine $(P G)$. Metode izračuna so take (Manum idr., 2005):

$$
\begin{aligned}
& i=1 / R A \\
& R A=2^{*}(P G-1) /(K-2) \\
& P G=S G /(K-1)
\end{aligned}
$$

$R A$ je relativna asimetrija, $K$ je število vozlišč in $S G$ je skupna globina vozlišča. Integracijska vrednost $i$ predstavlja stopnjo integracije posameznega vozlišča v sistem. Povprečna integracijska vrednost je povprečje teh vrednosti, ki skupaj z najnižjo in najvišjo vrednostjo pokaže skupno povezanost sistema. Višja ko je povprečna integracijska vrednost in višja ko je najnižja integracijska vrednost $\mathrm{v}$ sistemu, bolje so vozlišča povezana $\mathrm{s}$ preostalim sistemom. To pomeni, da ima sistem malo poti, na katerih se gnetejo obiskovalci, ki so prisiljeni uporabiti isto pot za potovanje iz enega dela sistema v drugega.

\subsection{Primerjava turistične rabe prostora na Dunaju in v Pragi}

Da bi primerjali grafa, smo izbrali 40 najbolj obiskanih vozlišč. To ni bilo težko, saj imata mesti podobno turistično ponudbo. Pri tem je bilo pomembno, da smo izloćili znamenitosti, ki so tako daleč od vozlišč, da jih obiskovalci ne morejo doseči peš. Dunaj ima pomembne turistične znamenitosti zunaj mestnega središča; na primer park Prater, palača Schönbrunn in stavbe, ki jih je zasnoval arhitekt Hundertwasser, so vsi zunaj središča. V Pragi pa sta na primer grad Višegrad in razgledni stolp Petrin najbolj obiskani znamenitosti zunaj cone za pešce $\mathrm{v}$ mestnem središču.

Integrirani turistični omrežji sledita že omenjenim zgodovinskim morfološkim strukturam. Grafa obeh mest kažeta nekaj pomembnih razlik. V Pragi so tri osi, opisane zgoraj, dobro vidne (slika 7). Turisti res uporabljajo Manesov most in grajske stopnice, ki povezujejo grad s starim židovskim pokopalǐ̌čem, nato pa obiščejo še sinagoge in preostale tamkajšnje zanimivosti, vendar drugje v mestu obstaja zelo malo podobnih povezav. Zato graf v glavnem sestavljajo vozlišča s samo dvema robovoma, ki povezujeta znamenitosti na turističnih poteh in s katerih ni mogoče zaviti, da bi si ogledali še kaj drugega. Najbolje povezane točke so na Karlovi ulici med Karlovim mostom in Starim mestnim trgom $(6,50-7,05)$. Pravzaprav vsi turisti ta del prečkajo vsaj enkrat. Najmanjša vrednost je pod $3,30 \%$ vseh vozlišč pa ima integracijsko vrednost nižjo od 4. Povprečna integracijska vrednost je 4,75, kar je zanimivo samo ob primerjavi z drugimi sistemi.

Dunaj ima dobro povezan centralni sistem, ki ga sestavljajo robovi in vozlišča ob mestni obvoznici (slika 8). Sistem vključuje celo nekaj znamenitosti zunaj obvoznice, na primer $\mathrm{MQ}$, tržnico Naschmarkt in palačo Belvedere; ti trije tvorijo veje z drevesno strukturo. Graf prostorske sintakse kaže najbolj povezana vozlišča okrog opere, ki ima integracijsko vrednost 9,62. Vsa vozlišča v mestnem središču imajo vrednosti nad 7,00, kar je v Pragi največja dosežena vrednost. Vse najmanjše vrednosti so nad 4, razen južnega dela okrog Belvedera. Povprečna integracijska vrednost celotnega centralnega turističnega omrežja na Dunaju znaša 6,16, kar je izredno visoko v primerjavi s Prago. 


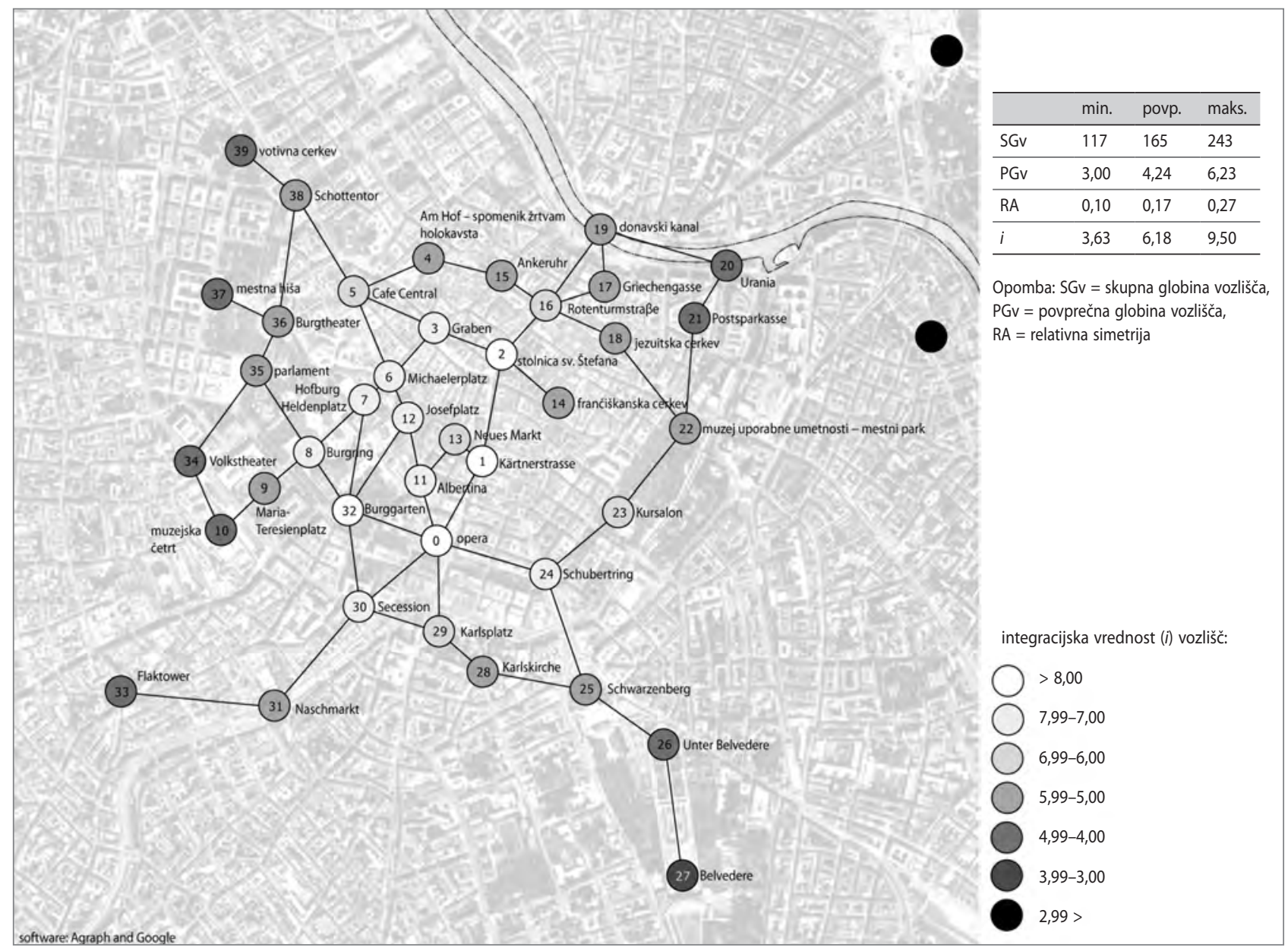

Slika 8: Sistem turističnega prostora za pešce na Dunaju leta 2011
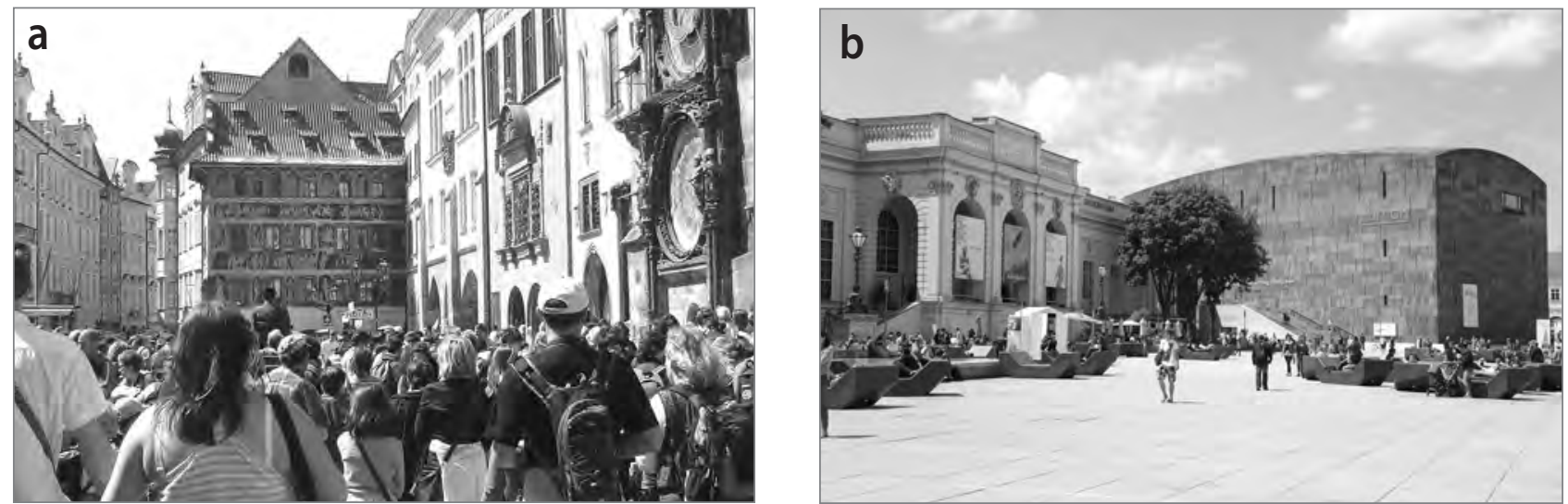

Slika 9: (a) Zgoščanje turistov v starem praškem mestnem jedru: Stari trg; (b) muzejska četrt na Dunaju: muzej moderne umetnosti in premično pohištvo (foto: (a) Bálint Kádár, (b) Alex Diem)

Graf Dunaja prikazuje zgoščeno kompleksno omrežje, v katerem imajo turisti različne možnosti za ogledovanje mestnega središča, medtem ko obiskujejo tamkajšnje znamenitosti. Graf Prage pa kaže, da mesto turistom nudi manj možnosti za odkrivanje novih prostorov kot Dunaj, medtem ko je število znamenitosti enako. Razlogi za tako nizko vrednost so posebna morfologija mesta s topografskimi ovirami na zahodnem bregu reke, sama reka, labirint srednjeveških ulic $\mathrm{v}$ starem mestnem jedru s samo eno označeno glavno potjo in dejstvo, da obvo- znica v vzhodnem delu mesta ne povezuje treh glavnih prej opisanih turističnih osi. Določeni novozgrajeni objekti so pomagali obogatiti turistični sistem mesta. $V$ zadnjih desetletjih so prenovili grajsko stopnišče in grajske vrtove in tako razširili ponudbo za grajske obiskovalce. Na bregovih reke Vltave so zgradili nove zanimivosti, kot so velikanski metronom na severu ter Plešoča hiša, spomenik žrtvam komunizma in muzej sodobnih umetnosti Kampa na jugu. Vendar so podobno storila tudi druga evropska mesta, da bi razširila svojo kulturno 
ponudbo in Dunaj pri tem ni bil izjema. Izgradnja MQ in objektov vzdolž donavskega kanala so bili najpomembnejši posegi, ki so razširili že tako gosto turistično mrežo (Kádár, 2012).

\section{Sklep}

Obravnavani srednjeevropski mesti imata podobno število znamenitosti in podobno kulturno okolje, zadnja leta pa ju obišče tudi enako število turistov (ki na spletu objavijo enako število fotografij s svojih potovanj). Kljub temu Dunaj ne doživlja enakih negativnih posledic kot Praga. Posebna morfologija obeh turističnih zgodovinskih mest ter različna ureditev njunih glavnih znamenitosti in turistične infrastrukture sta deloma razlog za razlike $\mathrm{v}$ turistični rabi. Te razlike lahko osvetlimo $\mathrm{z}$ grafičnim modelom analize sistema javnih prostorov, ki jih uporabljajo turisti.

Večina razlik v turistični rabi obeh mest je predvsem morfološke narave. Dunaj ima uravnoteženo turistično mrežo, saj ima njegovo središče jasno morfološko zgradbo. Glavna ovira starega mestnega jedra, srednjeveško obzidje, je bila porušena v 19. stoletju, na njenem mestu pa so bile zgrajene glavne ustanove (zdajšnje znamenitosti), ki so tako ustvarile nekakšen obroč, ki povezuje vse turistične znamenitosti znotraj in zunaj njega. Praga ima mnoge morfološke ovire, ki preprečujejo dobro povezanost njene turistične mreže. Mestno središče deli reka, hribovit svet pa preprečuje razvoj dobro povezanega cestnega omrežja. Zaradi močnega gibanja za ohranitev starih delov mesta vse od začetka 19. stoletja se je v Pragi ohranil vzorec srednjeveških ulic, urejenih v obliki labirinta, ki so bile namenjene boljši obrambi mesta (Hoffman in Musil, 1999). Dostopnost bi lahko izboljšali samo z izgradnjo novih mostov in določenih obsežnih urbanih kompozicij, ki bi središče mesta povezali z obrobjem.

Urbane morfologije turističnih zgodovinskih središč tako rekoč ni mogoče spremeniti, ampak ker turistični sistem znotraj urbanih struktur uporablja samo nekatere javne prostore in stavbe, lahko številne razširimo. Razpršenost enakega števila turistov v večjem prostoru vodi v manjšo gnečo. Tako poleg morfologije še en dejavnik določa turistično rabo mesta: urbanistično načrtovanje turistične infrastrukture. Za Dunajem je več kot 50 let uravnoteženega in načrtnega urbanističnega razvoja, pri čemer sta bila turistični menedžment in urbanistično načrtovanje pomembni dejavnosti. Blaginja prebivalcev je rastla skupaj s številom turističnih prihodov, lokalne storitve v mestnem središču pa so se razvijale skupaj s turističnimi. $\mathrm{V}$ Pragi tovrstna uravnotežena in načrtovana rast ni bila mogoča. Po padcu železne zavese je do decentralizacije državne oblasti in sprostitve vseh trgov prišlo hkrati z nenadnim povečanjem števila turističnih prihodov. Turistična infrastruktura se je zgoščala predvsem v ponovno privatiziranih nepremičninah ob najbolj priljubljenih turističnih znamenitostih na najpomembnejših zgodovinskih poteh $\mathrm{v}$ mestu.

Te razlike so jasno vidne na grafih turistične rabe prostora. Integracijske vrednosti, izračunane na podlagi sintaktične globine grafov, dokazujejo, da so znamenitosti na Dunaju med seboj veliko bolj povezane kot v Pragi, kar pomeni, da na Dunaju enako število turistov obišče več javnih prostorov. Pri enakem številu vozlišč ima praški sistem povprečno integracijsko vrednost 4,75, Dunaj pa 6,16. Zaradi tega je za Prago značilna gneča, saj morajo turisti določene javne prostore prečkati večkrat, če si želijo ogledati vse znamenitosti. O negativnih posledicah te turistične mreže, med drugim o tem, da domačini vse manj uporabljajo mestno središče in da so prenapolnjene ulice vse manj privlačne za turiste, so pisali mnogi raziskovalci (Johnson, 1995; Cooper in Morpeth, 1998; Simpson, 1999, in Deichmann, 2002). Podobnih izsledkov pa ni bilo objavljeno za Dunaj, v katerem enako število turistov obǐ̌če več javnih prostorov, saj so storitve bolj razpršene in omogočajo, da te prostore uporabljajo tudi lokalni prebivalci.

\section{Bálint Kádár}

Budapest University of Technology and Economics, Faculty of Architecture, Department of Urban Planning and Design, Budimpešta, Madžarska

E-pošta: balint.kadar@gmail.com

\section{Viri in literatura}

Alexander, C. (1965): A city is not a tree. Architectural Forum, 122(1), str. 58-61 in 122(2), str. 58-62.

Ashworth, G. J., in Turnbridge, J. E. (1990): The tourist-historic city. London, Belhaven Press.

Avstrijski statistični urad (1938): Statistisches Jahrbuch für Österreich 1938. Dunaj, Österreichisches Statistisches Landesamt.

Boerwinkel, H. W. J. (1995): Management of recreation and tourist behaviour at different spatial levels. V: Ashworth, G. J, in Dietvorst, A. G. J. (ur.): Tourism and spatial transformations-implications for policy and planning, str. 241-263. Wallingford, CAB International.

Bugarič, B. (2006): Preobrazbe javnega prostora; od modernizma do potrošništva. Urbani izziv, 17(1-2), str. 5-11. DOI: 10.5379/urbani-izziv-2006-17-01-02-001

Cooper, C., in Morpeth, N. (1998): The impact of tourism on residential experience in Central-Eastern Europe: The development of a new legitimation crisis in the Czech Republic. Urban Studies, 35(12), str. 22532275. DOI: $10.1080 / 0042098983872$

Crandall, D, in Snavely, N. (2012): Modeling people and places with internet photo collections. Communications of the ACM, 55(6), str. 52. DOI: $10.1080 / 0042098983872$

Češkoslovaški statistični urad (1938): Visitors to the spas of Czechoslovakia and to the capital, Prague. Praga.

Deichmann, J. I. (2002): International tourism and the sensitivities of central Prague's residents. Journal of Tourism Studies, 13(2), str. 41-52.

Franke, A. (1984:) Rukovět' cestovního ruchu. Praga, Merkur.

Frantz, M. D. (2005): From cultural regeneration to discursive gover- 
nance: Constructing the flagship of the "Museumsquartier Vienna" as a plural symbol of change. International Journal of Urban and Regional Research, 29(1), str. 50-66. DOI: 10.1111/j.1468-2427.2005.00569.x

Garrod, B. (2009): Understanding the relationship between tourism destination imagery and tourist photography. Journal of Travel Research, 47(3), str. 346-358. DOI: 10.1177/0047287508322785

Gede, M. (2012): Visualization methods of spatial distribution of geotagged photography. Prispevek je bil predstavljen na konferenci z naslovom Data is Beautiful, ki je potekala od 2. do 6. oktobra v Budimpešti na Madžarskem. Tipkopis.

Gilbert, D., in Clark, M. (1997): An exploratory examination of urban tourism impact, with reference to residents attitudes, in the cities of Canterbury and Guildford. Cities, 14(6), str. 343-352.

DOI: 10.1016/S0264-2751(97)00025-5

Girardin, F., Fiore, F. D., Ratti, C., in Blat, J. (2008): Leveraging explicitly disclosed location information to understand tourist dynamics: A case study. Journal of Location Based Services, 2(1), str. 41-56. DOI: 10.1080/17489720802261138

Gospodini, A. (2001): Urban design, urban space morphology, urban tourism: An emerging new paradigm concerning their relationship. European Planning Studies, 9(7), str. 925-934. DOI: 10.1080/09654310120079841

Hatz, G. (2008): Vienna. Cities, 25(5), str. 310-322. DOI: 10.1016/ j.cities.2008.02.002

Hayllar, B., in Griffin, T. (2005): The precinct experience: A phenomenological approach. Tourism Management, 26(4), str. 517-528. DOI: 10.1016/j.tourman.2004.03.011

Hillier, B. (1996): Space is the machine. Cambridge, Cambridge University Press.

Hoffman, L. M., in Musil, J. (1999): Culture meets commerce: Tourism in postcommunist Prague. V: Judd, D., in Fainstein, S. (ur.): The Tourist City, str. 179-197. New Haven, Yale University Press.

Hoffman, L. M., in Musil, J. (2009): Prague, tourism and the post-industrial city. Tourism. Chicago, Great Cities Institute College of Urban Planning and Public Affairs University of Illinois at Chicago.

Hollenstein, L., in Purves, R. S. (2010): Exploring place through user-generated content: Using Flickr to describe city cores. Journal of Spatial Information Science, 1(1), str. 21-48.

Jenkins, O. H. (2003): Photography and travel brochures: The circle of representation. Tourism Geographies, 5(3), str. 305-328. DOI: 10.1080/14616680309715

Ji, R., Gao, Y., Zhong, B., Yao, H., in Tian, Q. (2011): Mining flickr landmarks by modeling reconstruction sparsity. ACM Transactions on Multimedia Computing, Communications, and Applications, 7S(1), str. 1-22. DOI: 10.1145/2037676.2037688

Johnson, M. (1995): Czech and Slovak tourism patterns: Problems and prospects. Tourism Management, 16(1), str. 21-28.

DOI: 10.1016/0261-5177(94)00003-S

Kádár, B. (2012): Spatial patterns of urban tourism in Vienna, Prague and Budapest. V:. Szirmai, V., in Fassmann, H. (ur.): Metropolitan Regions in Europe, str. 277-312. Budimpešta, Austrian-Hungarian Action Fund.

Larsen, J. (2006): Geographies of tourist photography choreographies and performances. V: Falkheimer, J., in Jansson, A. (ur.): Geographies of Communication: The Spatial Turn in Media Studies, str. 241-258. Göteborg, Nordicom.

Lo, I. S., McKercher, B., Lo, A., Cheung, C., in Law, R. (2011): Tourism and online photography. Tourism Management, 32(4), str. 725-731. DOI: 10.1016/j.tourman.2010.06.001
Lynch, K. (1960): The image of the city. Cambridge, MA, MIT Press.

Manum, B., Rusten, E., in Benze, P. (2005): AGRAPH, software for drawing and calculating space syntax graphs. Prispevek je bil predstavljen na konferenci z naslovom 5th International Space Syntax Symposium Delft 2005, ki je potekala od 13. do 17. junija v Delftu na Nizozemskem. Tipkopis.

McKercher, B., in Lau, G. (2008): Movement patterns of tourists within a destination. Tourism Geographies, 10(3), str. 355-374. DOI: 10.1080/14616680802236352

McNeil, D. (1999): Globalisation and the European city. Cities, 16(3), str. 143-147. DOI: 10.1016/S0264-2751(99)00012-8

Medlik, S. (1990): Current issues focus on Eastern Europe. Tourism Management, 11(2), str. 95-98. DOI: 10.1016/0261-5177(90)90023-3

Modsching, M., Kramer, R., Hagen, K. Ten, in Gretzel, U. (2008): Using location-based tracking data to analyze the movements of city tourists. Information Technology \& Tourism, 10(1), str. 31-42. DOI: $10.3727 / 109830508785059011$

Nov, O., in Ye, C. (2010): Why do people tag? Motivations for photo tagging. Communications of the ACM, 53(7), str. 128-131. DOI: $10.1145 / 1785414.1785450$

Ourednicek, M., in Temelová, J. (2009): Twenty years after socialism: the transformation of Pragues inner structure. Studia Universitatis Babes-Boyai, Sociologia, 54(1), str. 9-30.

Pang, Y., Hao, Q., Yuan, Y., Hu, T., Cai, R., in Zhang, L. (2011): Summarizing tourist destinations by mining user-generated travelogues and photos. Computer Vision and Image Understanding, 115(3), str. 352-363. DOI: 10.1016/j.cviu.2010.10.010

Puczkó, L., in Rátz, T. (2000): The three forming one: Destination BPV. V: Ruddy, J., in Flanagan, S. (ur.): Tourism Destination Marketing. Gaining the Competitive Edge, str. 367-377. Dublin, Tourism Research Centre Dublin Institute of Technology.

Riganti, P., in Nijkamp, P. (2008): Congestion in popular tourist areas: A multi- attribute experimental choice analysis of willingness-to-wait in Amsterdam. Tourism Economics, 14(1), str. 25-44. DOI: $10.5367 / 000000008783554785$

Salingaros, N. A. (2004): Remarks on a city's composition. Journal of Design Research, 4(1). DOI: 10.1504/JDR.2004.009844

Salingaros, N. A. (2005): Principles of urban structures. Amsterdam, Techne Press.

Shoval, N., in Isaacson, M. (2010): Tourist mobility and advanced tracking technologies. New York, Routledge. DOI: 10.1016/j.tourman.2003.09.005

Shoval, N., in Raveh, A. (2004): Categorization of tourist attractions and the modelling of tourist cities: Based on the co-plot method of multivariate analysis. Tourism Management, 25(6), str. 741-750.

Simpson, F. (1999): Tourist impact in the historic centre of Prague: Resident and visitor perceptions of the historic built environment. The Geographical Journal, 165(2), str. 173-183. DOI: 10.2307/3060415

Stansfield, C. A. (1964): A note on the urban-nonurban imbalance in American recreational research. Tourism Review, 19(4), str. 196-200.

TourMIS (2012): City tourism in Europe. Available at: http://www.tourmis. info (sneto 10. 1. 2012).

Tsenkova, S. (2011): Potovanje v neznano: strateško prostorsko načrtovanje v posocialističnih mestih. Urbani izziv, 22(1), str. 5-21. DOI: 10.5379/urbani-izziv-2011-22-01-001

Urry, J. (1990): The tourist gaze - leisure and travel in contemporary societies. London, SAGE publications. 